\title{
PROFESSORS OF THE PRAGUE UTRAQUIST UNIVERSITY AND THEIR CAREERS IN THE URBAN MILIEU (1526-1622)
}

\author{
MAREK ĎURČANSKÝ
}

\begin{abstract}
The study is based on the prosopography of 93 professors, who have taught at the Prague Utraquist University in the years 1526-1622. It examines the careers of 63 of them, who have left the university and settled down in royal cities. They usually served in the intellectual professions (scribes, chancellors) or took part in the municipal self-government (councillors in town councils).
\end{abstract}

Keywords: Prague Utraquist University; prosopography; intellectual professions; urban history; history of education

DOI: $10.14712 / 23365730.2020 .32$

The sixteenth century and the first two decades of the seventeenth century were a time when links between the Bohemian towns and the Prague university were probably at their most intensive in the university's history. This phenomenon has already been examined from various perspectives in works including the synthetic histories by Zikmund Winter, ${ }^{1}$ studies by František Palacký ${ }^{2}$ and Jiří Pešek ${ }^{3}$ who focused on the system of municipal

1 Of Zikmund Winter's works, the following pay special attention to between towns and the Prague university: Zikmund WinTER, Děje vysokých škol pražských od secessí cizích národů po dobu bitvy bělohorské (14091622) [A History of Prague Universities from the Secession of Foreign Nations to the Time of the Battle of White Mountain (1409-1622)], Praha 1897; IDEM, O životě na vysokých školách pražských knihy dvoje. Kulturni obraz XV. a XVI. stoleti [Two Books on Life at Prague Universities. A Cultural Sketch of the Fifteenth and Sixteenth Century], Praha 1899; IDEM, Život a učení na partikulárních školách v Čechách v XV. a XVI. stoleti [Life and Learning at Latin Schools in Bohemia in the Fifteenth and Sixteenth Century], Praha 1901. On the older history of Prague university in English language cf. František KaVKA - Josef PETRÁŇ (eds.), A History of Charles University, vol. 1, Prague 2001. The most recent monograph concerning its early modern history is Mlada Holá, Studentské koleje pražské univerzity v pozdním středověku a raném novověku. Dějiny - správa-úrední písemnosti (do roku 1622) [Prague University Student Colleges in the Late Middle Ages and Early Modern Period. History - Administration - Official Documents (until 1622)], Praha 2017.

2 František Palacký (1929-2002) was a namesake of the famous Bohemian nineteenth-century historian František Palacký (1798-1876). František PALACKÝ, Města severozápadnich Čech a studium na universitách v 16. století [North Bohemian Towns and University Education in the Sixteenth Century], in: Sborník Pedagogické fakulty v Ústí nad Labem, řada dějepisná, Praha 1968, p. 27-63; IDEM, Obyvatelstvo českých měst a školní vzdělání v 16. a na začátku 17. století [The Population of Bohemian Towns and School Education in the Sixteenth and Early Seventeenth Century], Čs ̌̌H 18, 1970, p. 345-370.

3 Jiří PEŠEK, Univerzitni správa městských latinských škol v Čechách a na Moravě na přelomu 16. a 17. stoleti [University Administration of Municipal Latin Schools in Bohemia and Moravia in Late Sixteenth and Early Seventeenth Century], AUC-HUCP 30/2, 1990, p. 41-58; IDEM, The University of Prague, Czech Latin Schools and Social Mobility 1570-1620, History of Universities 10, 1991, p. 117-136; IDEM, Pražská univerzita, městské latinské školy a měštanské elity předbělohorských Čech [Prague University, Municipal Latin Schools, and Municipal Elites in Bohemia before the Battle of White Mountain], ČC̆H 89, 1991, p. 336-355; 
schools which connected to the university, or the prosopography of students compiled by František Šmahel ${ }^{4}$ and Petr Svobodný. ${ }^{5}$ Part of their research was inspired by the Handbook of Humanist Poetry by Josef Hejnic and Josef Martínek, ${ }^{6}$ which appeared in five volumes (and one volume of supplements) starting in the 1960s and its importance for research of the history of the Utraquist university and Bohemian towns is unparalleled. It remains the most complete source of critically sorted biographical data for the university and municipal intellectual elites during the abovementioned period.

This contribution focuses on the period of 1526-1622, a period between the election of Ferdinand I until the Jesuit order took over the university in Prague. The former date was a turning point rather in the history of Bohemian towns than in the history of the university. In the late fifteenth and early sixteenth century, royal towns of Bohemia as the 'third estate' represented a significant military, economic, and political power. They were so self-confident they were even willing to enter into open conflict with both of the higher estates, that is, the knights and the lords. The military and political strength of Bohemian royal towns was broken after the unsuccessful revolt against Ferdinand I in 1547, but they maintained their importance in economy and especially in cultural and intellectual life until the defeat of the subsequent revolt in 1618-1620.

The relationship between the towns and university rested on three main pillars. First of all, it was their political cooperation. The Carolinum was a place where non-Catholic nobles and municipal politicians traditionally met. Leaders of the 'third estate' were often graduates of the Utraquist university, which was especially helpful when interests of the university were to be voiced and argued for at meetings of the Land Diet. Moreover, the university was located in the Bohemian capital, which strengthened its ties especially to the Old Town of Prague. To a lesser extent, though, it also bred tensions and conflicts, for instance due to the separate academic jurisdiction. The second pillar of relations between the town and the university can be identified with the places of origin of university students and professors. According to the results of František Šmahel's prosopographical research, $63 \%$ of graduates of the Utraquist university came from Bohemian royal towns, $28 \%$ from manorial towns, and $9 \%$ from villages. ${ }^{7}$ Vast majority of graduates eventually returned to their native towns as headmasters of municipal schools but for the most part, they soon joined the local economic and political elites thanks to their intellectual skills, advantageous marriages, or, in many cases, a combination of the two. This was enabled

IDEM, Měštanská vzdělanost a kultura v předbělohorských Čechách 1547-1620 (V̌̌ední dny kulturního života) [Municipal Education and Culture in Bohemia before the Battle of White Mountain 1547-1620], Praha 1993, p. 30-58.

4 The latest version in Czech: František ŠMAHEL, Existenční vyhlídky a kariéry univerzitních humanistů [Future Prospects and Careers of University Humanists], in: idem, Alma Mater Pragensis. Studie k počátkům Univerzity Karlovy, Praha 2016, p. 550-559; see also the German version: IDEM, Die Karlsuniversität Prag und böhmische Humanistenkarrieren, in: idem, Die Prager Universität im Mittelalter - The Charles University in the Middle Ages. Gesammelte Aufsätze - Selected Studies, Leiden - Boston 2007, p. 196-209.

5 Petr SvobodnÝ, Sociální a regionální struktura literárně činných absolventů pražské univerzity $v$ letech 1500-1620 [Social and Regional Structure of Graduates of the Prague University in 1500-1620 Who Developed Literary Activities], AUC-HUCP 26/1, 1986, p. 7-36.

6 Josef HeJNIC - Jan MARTíneK, Rukovět’ humanistického básnictví v Čechách a na Moravě. Enchiridion renatae poesis in Bohemia et Moravia cultae [A Handbook of Humanist Poetry in Bohemia and Moravia], vol. 1-6, Praha 1966-2011.

7 František Šmahel - Miroslav Truc, Studie k dějinám Univerzity Karlovy v letech 1433-1622 [A Study on the History of Charles University in 1433-1622], in: F. ŠMAHEL, Alma mater Pragensis, p. 411-458, here p. 428. 
by the third aspect of the relationship between the towns and the university: there existed a network of municipal schools supervised by the rector magnificus who traditionally had the right to appoint headmasters of municipal Latin schools. This system fully developed in the second half of the sixteenth century. It had its own hierarchy and holders of the most prestigious positions at municipal schools in Prague and large royal towns were at the same time possible candidates for professorships in Carolinum. It must be noted, however, that when offered such an opportunity, not all nominees decided to accept a university position and abandon their current life.

Zikmund Winter described the reasons why university graduates sometimes viewed professorship at the Utraquist university more as a burden than as honour. There were several factors at play: the limitations that went with mandatory celibacy (which was abolished only after 1609), life in a closed college community, but also smaller incomes and less prestige than one could achieve in the course of a career in an urban milieu. According to Zikmund Winter, ${ }^{8}$ in $1547-1609$ only 20 from 69 professors remained at the university until the end of their life. This proportion is similar to the results of the most detailed research undertaken by František Šmahel. ${ }^{9}$

Moreover, we should also take into account the graduates who were elected by professors to fill a vacant position in the Carolinum but rejected their appointment. Although such refusal was a breach of the university statutes, it happened repeatedly, and professors had limited powers to enforce their decision. Among the candidates who preferred marriage and another career, we find for instance Pavel Stránský ze Zapské Stránky (1583-1657), author of a popular compendium Respublica Bojema and municipal councillor in the town of Leitmeritz, or Matthias Borbonius z Borbenheimu (1566-1629), one of the most eminent physicians of Rudolfinian Prague. ${ }^{10}$ When it came to university appointments, opposition on the part of the administration of various towns may have also played a significant role, because candidates for professorship usually served as headmasters and municipalities sometimes did not want to lose competent and popular employees.

In the following prosopographical analysis, we focus especially on those scholars who accepted a professorship but later left the university to build a career in a municipal environment. In particular, I would like to present preliminary results which include the data of 63 persons concerning their engagement in municipal administration and related offices. This research was undertaken as part of a grant project 'Universitas magistrorum. Professors at Prague University 1458-1622'. Once the database of professors as one of the project results is finished, the total number of examined persons may further increase ${ }^{11}$ but not significantly so. I did not include scholars who did not accepted a university appointment to professorship that was offered to them or those who accepted it but died before they could start teaching.

During the period in question, 24 professors $^{12}$ from the 93 so far examined died without ever leaving their position in Carolinum. Most of these men chose university and teaching

Z. WINTER, $O$ životě, p. 136.

9 F. ŠMAHEL, Existenční vyhlidky, p. 555, 558, tab. 3.

10 Z. Winter, O životě, p. 127.

11 There are several persons whose inclusion in the database is debatable.

12 Jan Adami Bystřický z Bochova, Šebestián Aerichalcus, Martin Bacháček z Nauměřic, Vavřinec Benedicti z Nudožer, Jan Campanus Vodňanský, Petr Codicillus z Tulechova, Jan Colonius, Jan Crispus, Petr Crispus, 
as their proper place in life but some of them died relatively young (three died within the first three years after their appointment).

Then there are six special cases, ${ }^{13}$ such as those of three professors who came from the lower nobility or another who left the Carolinum to become an Utraquist pastor. I will not describe these special cases in detail because they are not completely relevant to the subject of this paper, although the subject of former professors functioning as Utraquist priests is also connected with the urban milieu. ${ }^{14}$ Let me thus focus on the 63 professors who left the Carolinum to marry and become burghers ${ }^{15}$ in Bohemian towns.

Table 1 - Places of origin and places of careers

\begin{tabular}{|l|c|c|}
\hline Location & Place of birth & Domicile \\
\hline Prague (particular town not indicated) ${ }^{16}$ & 6 & 2 \\
\hline The Old Town of Prague & 2 & 17 \\
\hline The New Town of Prague & 2 & 2 \\
\hline The Lesser Town of Prague & 3 & 4 \\
\hline Žatec / Saaz & 3 & 3 \\
\hline Kutná Hora / Kuttenberg & 2 & \\
\hline Litoměřice / Leitmeritz & 2 & 1 \\
\hline Nový Bydžov / Neu Bidschow & 3 & 2 \\
\hline Rakovník / Rakonitz & 2 & 2 \\
\hline Sušice / Schüttenhofen & & 4 \\
\hline Louny / Laun & 1 & 5 \\
\hline Hradec Králové / Königgrätz & 10 & \\
\hline Kolín / Kolin & 17 & $\mathbf{6 3}$ \\
\hline Other royal towns & 8 & \\
\hline Manorial towns & 2 & \\
\hline Villages & $\mathbf{6 3}$ & \\
\hline Unknown & & \\
\hline Total & & \\
\hline
\end{tabular}

This table shows a comparison between the regional origin and towns where former Carolinum professors resided after leaving the university. This group includes also professors

Jindřich Curius Dvorský z Helfenburka, Matěj Dvorský z Hájku, Petr Fradelius Štiavnický, Jan Kocmánek (Gotsmanius), Jan Zahrádka (Hortensius), Jan Chorinnus, Martin Klatovský z Betléma, Matěj Korambus, Ondřej Mitýsko, Trojan Nigellus z Oskořína, Jan Orphaeus z Chotěřiny, Prokop Poeonius, Simeon Skála z Kolínce, Jiří Sušil, and Václav Zelotýn z Krásné Hory.

13 Albert Mikuláš z Kaménka, Matouš Collinus z Chotěřny, Oldřich Humpolec z Prostiboře, Jan Jessenius a Jessen, Jan Matyáš ze Sudetu, and Pavel Pressius.

14 This subject will be dealt with in a separate study.

15 This means they were accepted by the town council as burghers (měšt'an, soused) with all duties, rights, and advantages stated in the municipal statutes. Where a person changed their domicile, the last one is listed here.

16 In early modern times, Prague, the capital city of Bohemia, consisted of three independent royal towns: the Old Town (Staré Město), New Town (Nové Město), and Lesser Town (Malá Strana). In 1598, Emperor Rudolf II promoted also Hradschin (Hradčany), a small town adjacent to the Prague castle, to the rank of royal town. 
active after the abolition of academic celibacy who managed to combine professorship with a career in a municipal environment. We can clearly see that the regional origin of professors more or less corresponds to František Šmahel's conclusions about the dominance of royal towns. On the other hand, we can also see the attractive power of the capital as far as subsequent careers were concerned. Over $60 \%$ of former professors (39 of 63) stayed within the walls of one of the towns of Prague. Especially the Old Town and the New Town of Prague had much to offer and we can be sure that many scholars were part of the network of political and intellectual elites of both of these towns. Aside from Prague, former academics went on to establish their subsequent careers in royal towns in Central Bohemia or in the largest urban centres with well-known schools, such as Leitmeritz, Saaz, and Laun in the north-western part of the country, or Königgrätz in north-eastern Bohemia. None chose a manorial town: this was most likely due not only to better conditions and higher prestige of royal towns but because of the degree of personal freedom (in manorial towns, burghers were required to pledge allegiance to the town's lord). In ten cases, professors simply returned to the place of their origin (Prague, Leitmeritz, or Sušice/Schüttenhofen).

Table 2 - Careers of former professors in municipal milieu (OTP = Old Town of Prague; NTP = New Town of Prague): municipal and royal offices and intellectual professions

\begin{tabular}{|c|c|c|}
\hline Office & Nature of the office & Number of persons (town) \\
\hline Chancellor of the OTP or NTP & \multirow[t]{4}{*}{ Municipal employees } & 5 (3 in NTP, 2 in OTP) \\
\hline Scribes in the town chancelleries & & $\begin{array}{l}20 \text { (8 in NTP, } 4 \text { in OTP, } 8 \text { in } \\
\text { large royal towns })\end{array}$ \\
\hline Scribes in other offices & & 2 (OTP, Kuttenberg) \\
\hline Headmasters of important schools & & $\begin{array}{l}5 \text { (3 in Leitmeritz, } 1 \text { in Saaz, } 1 \text { in } \\
\text { NTP) }\end{array}$ \\
\hline Councillors of the Appellate Court & \multirow{3}{*}{$\begin{array}{l}\text { Royal offices connected with the } \\
\text { urban environment }\end{array}$} & 3 \\
\hline Royal reeves & & 2 (2 in Kolin) \\
\hline Portreeve of the vineyards or Prague & & 1 \\
\hline Mayors & \multirow{6}{*}{$\begin{array}{l}\text { Town officials (municipal } \\
\text { government) }\end{array}$} & 9 \\
\hline Councillors of the town councils & & 17 \\
\hline Town elders & & 1 (Chrudim) \\
\hline 'Desetipáni' (Zehnter) $)^{17}$ & & 3 (2-OTP, 1 - NTP) \\
\hline School inspectors & & 5 (Laun, Kolin, Chrudim, OTP) \\
\hline 'Viri literati' fraternity & & 4 (Laun, Kolin, Chrudim) \\
\hline Physicians & \multirow[t]{2}{*}{$\begin{array}{l}\text { Independent intellectual } \\
\text { professions }\end{array}$} & $\begin{array}{l}7 \text { ( } 4 \text { in OTP, } 1 \text { in Lesser Town } \\
\text { of Prague, } 1 \text { in Leitmeritz, } 1 \text { in } \\
\text { Königgrätz) }\end{array}$ \\
\hline Lawyers & & 2 (OTP) \\
\hline
\end{tabular}

17 This office rendered decisions in cases of smaller debts. Cf. Jindřich ŠEBÁNEK, Desetipanský úrad Starého města pražského a jeho knihy. Z dějin městské správy a diplomatiky městských knih [The Office of 'Zehnter' in the Old Town of Prague and Its Records. From the History of Municipal Administration and the Diplomatics of Town Books], Sborník př́spěvků k dějinám hlavního města Prahy V/2, 1932, p. 767-929. This study includes the list of members. 
Table 2 shows the careers of former professors or, after the abolition of celibacy, the parallel careers of professors in the municipal environment. Professions and offices are divided in four basic groups.

Chancellors and scribes were employed by the town and they were responsible to its municipal council. ${ }^{18}$ These positions were probably the most important and in large towns also the best paid ones. Former professors were mostly employed as first, i.e. senior, scribes or, in fewer cases, they even became chancellors of the Old Town and New Town of Prague. Chancellors were in charge of town chancelleries and supervised the work of lower-ranking staff. In late sixteenth and early seventeenth century, most scribes in royal towns were graduates of the Prague Utraquist university with a bachelor or master's degree. ${ }^{19}$ Headmasters of municipal schools, too, were town employees but former professors opted for such positions only in case of the most prestigious schools and for a limited time.

The second group includes professors who were appointed to royal offices established after the defeat of the first revolt of the Bohemian Estates in 1547 to strengthen the sovereign's control over royal towns. The Appeal Court (Apelační soud, Apellationsgericht) ${ }^{20}$ was the highest legal institution of municipal law and the centre of learned jurisprudence. Its judges examined and confirmed or overturned the decisions of municipal courts in Bohemia. The post of royal reeve ${ }^{21}$ was established in Bohemian royal towns also in 1547 based on an Austrian model of this office. Royal reeves were supposed to defend the political and fiscal interests of the sovereign in individual towns. In practice, they were mostly chosen from the ranks of the most experienced and most prominent burghers who could be expected to take into consideration also local, municipal interests, which made their position somewhat ambivalent. After 1547, the portreeves of vineyards ('perkmistr hor viničných') of Prague found themselves in a similarly schizophrenic position in-between the sovereign and the municipality. This originally municipal office was turned into a royal one by Emperor Ferdinand I. ${ }^{22}$ Generally speaking, however, engagement of former professors in royal offices was not very frequent.

As noted above, the scholars who settled down and married in Bohemian towns usually belonged to the local political, economic, and intellectual elites and as such, they often took part in the work of various offices of municipal self-government. The most important

18 Documenta Pragensia Supplementa IX, 2018 (= Úřední písemná kultura v českých a moravských městech ve středověku a raném novověku [Official Written Culture in Bohemian and Moravian Towns in the Middle Ages and Early Modern Era], ed. Jan HrdinA - Kateřina Jí̌ovÁ).

19 Marek DunČAnskÝ, Pisaři městských kanceláři a předbělohorská univerzita: na cestě k širšímu pohledu [Town Scribes and Prague University in the pre-White Mountain Era: Moving Towards a Broader View], ibidem, p. 219-236.

20 Recently on the subject: Klára WoItschovÁ, ,....což slušného a spravedlivého jest fedrovati... “ Personální obsazeni pražského apelačního soudu v letech 1548-1783 [“...in support of those who are decent and righteous...': Personnel Composition of Prague Appeal Court in 1548-1783], Pelhřimov 2010.

21 The most important study on royal reeves is František RouBík, Královští rychtáři v pražských i jiných městech v letech 1547 až 1783 [Royal Reeves in Prague and Other Towns, 1547-1783], Sborník příspěvků k dějinám hlavního města Prahy 6,1930, p. 265-355. Recently on the topic, with focus on the situation of dower towns (a specific category of royal towns) in eastern Bohemia: David NovotnÝ, Královšti rychtári ve východočeských zemépanských městech v době predbělohorské [Royal Reeves in the Royal Towns of Eastern Bohemia Before the Battle of White Mountain], Olomouc 2012.

22 Marie VÁlková-FrÝzová, Úřad perkmistra hor viničných [The Office of Portreeve of Vineyards], Sborník př́spěvků k dějinám hlavního města Prahy 6, 1930, p. 1-148. Master Tomáš z Javořice held the office in 1543-1545, i.e. before the reform introduced by Ferdinand I. 
administrative body in a Bohemian town was a town council ${ }^{23}$ and in fact, over one third of the examined group of former academics served in a town council at some point in their lives. All royal and most manorial towns were administered by councils consisting of twelve councillors (only in the Old and New Town of Prague was the number higher). Councillors alternated every four weeks at the post of a burgomaster (purkmistr) who presided over council meetings and represented the whole of the local urban community. The first of these twelve councillors who was appointed to start the process of rotation at the post of burgomaster was called a mayor (primátor, primas). This post was most prestigious in a town council, but actual executive power rested in the hands of whoever was the current burgomaster. The former or future town councillors often belonged to a collective body of town elders (obecní starší), who were supposed to exert supervision over the town council especially in economic matters.

It ought to be noted that membership in a town council as the highest municipal administrative body could not be combined with the post of a town scribe or chancellor. This restriction did not, however, apply to lower municipal offices. Royal towns had large lower administrative bodies and various commissions supervised public life down to minute details. Former professors and graduates of the Utraquist university in general were often active as school inspectors or elders of the fraternity of 'viri literati' (literáti, Literaten). Both offices required linguistic and musical skills and school inspectors often had former experience with teaching at Latin schools.

Although the Prague Utraquist university had no faculty of medicine or law, its graduates often made a career in these fields, too. Some, but by far not all of them, received education in these areas at foreign universities. The Prague conurbation and large royal towns offered possibilities for careers in independent learned professions in law and medicine, but former university professors did not pursue these careers often. They were more frequently tempted by municipal positions and clearly, it was easier to use legal skills as a direct employee of the town. The career of Pavel Kristián z Koldína, scribe in the New Town of Prague and one of the authors of the Bohemian Code of Municipal Law (Práva městská Království českého), is but one example of this phenomenon.

Results of the prosopographical research clearly demonstrate a close relationship between the Utraquist university and Bohemian towns, especially royal towns. Approximately two thirds of its former professors in 1526-1622 left the university to marry and build a career in a municipal milieu or, after the abolition of celibacy, had two parallel careers. The range of position they accepted was wide but most frequently, they served in the most prestigious intellectual professions, i.e. as scribes or chancellors, in municipal self-governments. Former professors who were financially secure thanks to an advantageous marriage or prospering trade usually participated in the work of the highest administrative bodies of the royal towns as town councillors. Further research and completion of the database 'Universitas magistrorum' will no doubt describe the links between university professors and municipal milieu in even more detail. Even so, one may suppose that even this further research will confirm the basic trends presented in this paper.

23 On municipal self-government in Early Modern Bohemia, see Olga FeJTovÁ - Jiř̌́ PeŠEK - Václav LedvinKA (eds.), Osm set let pražské samosprávy [Eight Hundred Years of Prague Self-Government], Praha 2002 (= Documenta Pragensia 21). 


\section{Appendix: A list of former professors of the Utraquist university with subsequent or parallel career in urban environment}

To make the results of the prosopographical research verifiable, a list of examined scholars is attached. Former professors are listed in an alphabetical order by family name; the list of sources in the footnotes is limited to positions, including the results of recent research concerning the individual professors and their engagement in the municipal offices. Older literature was thoroughly reviewed by authors of the relevant entries in the Handbook of Humanist Poetry (Rukovět' humanistického básnictví), which remains the most authoritative source of information for the prosopography. Term councillor means the member of town council except if not indicated otherwise. OTP $=$ Old Town of Prague, NTP $=$ New Town of Prague

\begin{tabular}{|c|c|c|c|c|c|c|}
\hline & Name & $\begin{array}{l}\text { Place and year of } \\
\text { birth and death }\end{array}$ & $\begin{array}{l}\text { Graduation at } \\
\text { the Utraquist or } \\
\text { other university }\end{array}$ & Professorship & Domicile & $\begin{array}{l}\text { Career in the urban } \\
\text { milieu } \\
\text { (office and/or trade) }\end{array}$ \\
\hline 1. & $\begin{array}{l}\text { Daniel Adam } \\
\text { z Veleslavína }\end{array}$ & $\begin{array}{l}\text { Prague } 1546- \\
\text { Prague } 1599\end{array}$ & $\begin{array}{l}\text { Bc. } 1568 \\
\text { M. } 1569\end{array}$ & $1572-1576$ & OTP & $\begin{array}{l}\text { Zehnter 1584-1590; } \\
\text { printer }\end{array}$ \\
\hline 2. & Mikuláš Alethinus & $\begin{array}{l}\text { Kolin? } 1540- \\
\text { Kolin } 1586\end{array}$ & $\begin{array}{l}\text { Bc. } 1564 \\
\text { M. } 1565\end{array}$ & $1567-1573 ?$ & Kolin & $\begin{array}{l}\text { Scribe in OTP, mayor } \\
\text { in Kolin } 1582-1583 \text {, } \\
\text { then royal reeve in } \\
\text { Kolin }\end{array}$ \\
\hline 3. & $\begin{array}{l}\text { Zikmund Antoch } \\
\text { z Helfenburka }{ }^{24}\end{array}$ & $\begin{array}{l}\text { Prague } 1508 \text { - } \\
\text { Prague } 1552\end{array}$ & $\begin{array}{l}\text { Bc. } 1528 \\
\text { M. } 1534\end{array}$ & $1536-1543$ & OTP 1543 & \\
\hline 4. & $\begin{array}{l}\text { Jan Aquila } \\
\text { z Plavče }\end{array}$ & $\begin{array}{l}\text { NTP? }- \text { NTP } \\
1573 \text { or } 1574\end{array}$ & $\begin{array}{l}\text { Wittenberg Bc. } \\
1540 \\
\text { M. } 1543\end{array}$ & $?$ & NTP & Councillor since 1550 \\
\hline 5. & $\begin{array}{l}\text { Václav Arpinus } \\
\text { z Dorndorfu }\end{array}$ & $\begin{array}{l}\text { Böhmisch } \\
\text { Kamnitz 1515? - } \\
\text { Saaz 1583? }\end{array}$ & $\begin{array}{l}\text { Wittenberg M. } \\
1540\end{array}$ & $1540-1542 ?$ & Saaz & Mayor 1564-1573 \\
\hline 6. & Jan Artophidius & $\begin{array}{l}\text { Bischofteinitz- } \\
\text { Laun } 1567\end{array}$ & $\begin{array}{l}\text { Bc. } 1543 \\
\text { M. } 1545\end{array}$ & $1545-1557 ?$ & Laun & $\begin{array}{l}\text { Headmaster } 1557- \\
1560 \text {; later councillor } \\
\text { and mayor, school } \\
\text { inspector, member of } \\
\text { the 'viri literati' }\end{array}$ \\
\hline 7. & $\begin{array}{l}\text { Daniel Basilius } \\
\text { z Deutschenberka }\end{array}$ & $\begin{array}{l}\text { Deutschliptsch } \\
1585 \text { - Lesser } \\
\text { Town of Prague } \\
1628\end{array}$ & $\begin{array}{l}\text { Bc. } 1609 \\
\text { M. } 1612\end{array}$ & $1615-1622$ & $\begin{array}{l}\text { Lesser } \\
\text { Town of } \\
\text { Prague }\end{array}$ & $\begin{array}{l}\text { Councillor 1619-1620, } \\
\text { mayor } 1622^{25}\end{array}$ \\
\hline
\end{tabular}

24 The Biographical Dictionary of the Czech Lands lists him as a town councillor in the Old Town of Prague. $<$ https://slovnik.seznam.cz/preklad/cesky_anglicky/uv\%C3\%A1d\%C4\%9Bt> (21 April 2020), but published lists of councillors do not include his name. Jaroslav DoušA, Seznamy konšelù ve staroměstských radách z let 1547-1650 [Lists of councillors in the town councils of the Old Town of Prague], Pražský sborník historický 14, 1981, p. 68-72; Václav Vladivoj ToмEK, Dějepis města Prahy [History of the City of Prague], IX, Praha 1897 , p. 4166 .

25 Eva Frimmová, Daniel Basilius (1585-1628). Život a dielo [Daniel Basilius (1585-1628). His Life and Work], Bratislava 1997, p. 25-27. 


\begin{tabular}{|c|c|c|c|c|c|c|}
\hline & Name & $\begin{array}{l}\text { Place and year of } \\
\text { birth and death }\end{array}$ & $\begin{array}{l}\text { Graduation at } \\
\text { the Utraquist or } \\
\text { other university }\end{array}$ & Professorship & Domicile & $\begin{array}{l}\text { Career in the urban } \\
\text { milieu } \\
\text { (office and/or trade) }\end{array}$ \\
\hline 8. & $\begin{array}{l}\text { Jan Berka } \\
\text { Choceňský }\end{array}$ & $\begin{array}{l}\text { Choceň } 1494 \text { - } \\
\text { Prague } 1545\end{array}$ & & $1530 \mathrm{~s}$ & OTP & $\begin{array}{l}\text { Councillor } \\
1543-1545^{26}\end{array}$ \\
\hline 9. & $\begin{array}{l}\text { Marek Bydžovský } \\
\text { z Florentina }\end{array}$ & $\begin{array}{l}\text { Neu-Bidschow } \\
1540 \text { - NTP } 1612\end{array}$ & $\begin{array}{l}\text { Bc. } 1559 \\
\text { M. } 1565\end{array}$ & $1567-1604$ & $\begin{array}{l}\text { NTP } \\
1604\end{array}$ & $\begin{array}{l}\text { Councillor } \\
1608-1611^{27}\end{array}$ \\
\hline 10. & $\begin{array}{l}\text { Matěj Bydžovský } \\
\text { z Aventýna }\end{array}$ & $\begin{array}{l}\text { Neu-Bidschow } \\
1520 \text { - NTP } 1590\end{array}$ & $\begin{array}{l}\text { Bc. } 1542 \\
\text { M. } 1545\end{array}$ & $1551 ?-1559$ & NTP & $\begin{array}{l}\text { Scribe } 1575-1585 \text {, } \\
\text { chancellor, Zehnter }\end{array}$ \\
\hline 11. & $\begin{array}{l}\text { Jakub Codicillus } \\
\text { z Tulechova }\end{array}$ & $\begin{array}{l}\text { Seltchan - NTP } \\
1576\end{array}$ & $\begin{array}{l}\text { Bc. } 1548 \\
\text { M. } 1550\end{array}$ & $1550-1557 ?$ & NTP & $\begin{array}{l}\text { First scribe (1557) and } \\
\text { vice-chancellor of the } \\
\text { NTP }\end{array}$ \\
\hline 12. & $\begin{array}{l}\text { Václav Crussinius } \\
\text { z Dalmanhorstu }\end{array}$ & $\begin{array}{l}\text { Hohenmauth - } \\
\text { Königgrätz } 1552\end{array}$ & $\begin{array}{l}\text { Bc. } 1534 \\
\text { M. } 1541\end{array}$ & $\begin{array}{l}1541 ?- \\
1546 / 47\end{array}$ & Königgrätz & \\
\hline 13. & $\begin{array}{l}\text { Jan Cypriani } \\
\text { Mšenský }\end{array}$ & Mšeno - Čáslav? & M. 1576 & $1576-1579$ & Č́slav & Scribe in Čáslav \\
\hline 14. & $\begin{array}{l}\text { Václav Sr. Cyrillus } \\
\text { z Kyršfeldu }\end{array}$ & $\dagger$ after 1590 & $\begin{array}{l}\text { Bc. } 1552 \\
\text { M. } 1561\end{array}$ & $1563 ?-1564$ & NTP & First scribe in $\mathrm{NTP}^{28}$ \\
\hline 15. & Martin Faber & $\begin{array}{l}\text { Rakonitz - } \\
\text { Chrudim } 1599\end{array}$ & $\begin{array}{l}\text { Bc. } 1577 \\
\text { M. } 1579\end{array}$ & 1581 & Chrudim & $\begin{array}{l}\text { Councillor 1583-1599, } \\
\text { school inspector, } \\
\text { member of 'viri } \\
\text { literati' }\end{array}$ \\
\hline 16. & Jan Fortius Chyba & $\begin{array}{l}\text { Kaurim (Kouřim) } \\
1517 \text { - Prague } \\
1590\end{array}$ & $\begin{array}{l}\text { Bc. } 1537 \\
\text { M. } 1541\end{array}$ & $1542 ?-1544$ & ОТР & 1571-1581 Zehnter \\
\hline 17. & $\begin{array}{l}\text { Matěj Gryllus } \\
\text { z Gryllova }\end{array}$ & $\begin{array}{l}\text { Rakonitz } 1551 \text { - } \\
\text { Saaz } 1611\end{array}$ & $\begin{array}{l}\text { Bc. } 1570 \\
\text { M. } 1576\end{array}$ & $1576-1582$ & Saaz & Scribe \\
\hline 18. & $\begin{array}{l}\text { Tadeáš Hájek } \\
\text { z Hájku²9 }\end{array}$ & $\begin{array}{l}\text { Prague } 1525- \\
\text { Prague } 1600\end{array}$ & $\begin{array}{l}\text { Bc. } 1550 \\
\text { M. } 1552\end{array}$ & $\begin{array}{l}1553 \\
?-1558\end{array}$ & $\begin{array}{l}\text { Lesser } \\
\text { Town of } \\
\text { Prague? }\end{array}$ & Physician \\
\hline 19. & $\begin{array}{l}\text { Zikmund } \\
\text { Heniochus }\end{array}$ & $\begin{array}{l}\text { Leitmeritz - } \\
\text { Leitmeritz } 1614\end{array}$ & $\begin{array}{l}\text { Bc. } 1570 \\
\text { M. } 1572\end{array}$ & $1575 ?$ & Leitmeritz & $\begin{array}{l}\text { Rector of college in } \\
\text { Leitmeritz }^{30}\end{array}$ \\
\hline 20. & Bartoloměj Hircius & $\begin{array}{l}\text { Pisek - Laun } \\
1622\end{array}$ & $\begin{array}{l}\text { Bc. } 1595 \\
\text { M. } 1596\end{array}$ & $1597-1599$ & Laun & Scribe $1599-1622$ \\
\hline
\end{tabular}

26 V. V. Tомек, Dějepis města Prahy, IX, p. 417.

27 Jaroslava Mendelová, Rada Nového Města pražského v letech 1600-1650 [Town Council of the New Town of Prague, 1600-1650], Pražský sborník historický 29, 1996, p. 91.

28 J. Mendelová, Soupis písařu Nového Města pražského z let 1530 (1547) - 1650 [List of Scribes in the New Town of Prague 1530 (1547) - 1650], Documenta Pragensia Supplementa IX, 2018, p. 249.

29 Knighted in 1571.

30 Oldřich Kotyza - Jan Smetana - Jindřich Tomas a kol., Dějiny města Litoměric [History of the Leitmeritz Town], Litoměřice 1997, p. 399. 


\begin{tabular}{|c|c|c|c|c|c|c|}
\hline & Name & $\begin{array}{l}\text { Place and year of } \\
\text { birth and death }\end{array}$ & $\begin{array}{l}\text { Graduation at } \\
\text { the Utraquist or } \\
\text { other university }\end{array}$ & Professorship & Domicile & $\begin{array}{l}\text { Career in the urban } \\
\text { milieu } \\
\text { (office and/or trade) }\end{array}$ \\
\hline 21. & $\begin{array}{l}\text { Adam Huber } \\
\text { z Riesenpachu }\end{array}$ & $\begin{array}{l}\text { Groß Meseritsch } \\
1546 \text { - NTP } 1613\end{array}$ & $\begin{array}{l}\text { Wittenberg } \\
\text { Dr. Med. } 1577\end{array}$ & $\begin{array}{l}1567-1580 \\
\text { and in } 1612\end{array}$ & $\begin{array}{l}\text { Leitmeritz, } \\
1588 \text { OTP, } \\
1593 \text { NTP }\end{array}$ & Physician \\
\hline 22. & \begin{tabular}{|l} 
Tomáš \\
Hussinecius
\end{tabular} & $\begin{array}{l}\text { Wodnian } 1530 ?- \\
\text { OTP } 1582\end{array}$ & $\begin{array}{l}\text { Bc. } 1548 \\
\text { M. } 1552 \\
\text { Dr. Med. Rome }\end{array}$ & $1556 ?-1569$ & OTP & Physician \\
\hline 23. & Tomáš z Javořice & $\begin{array}{l}\text { Rakonitz - } \\
\text { Prague } 1556\end{array}$ & $\begin{array}{l}\text { Bc. } 1515 \\
\text { M. } 1518\end{array}$ & $1518-1528$ & OTP & $\begin{array}{l}\text { Scribe, later } \\
\text { chancellor, } 1543-1545 \\
\text { portreeve of vineyards, } \\
\text { town councillor, since } \\
1558 \text { councillor of the } \\
\text { Appeal Court }\end{array}$ \\
\hline 24. & $\begin{array}{l}\text { Jiří Ježííšek } \\
\text { (Jesulus) }\end{array}$ & OTP-OTP? & $\begin{array}{l}\text { Bc. } 1508 \\
\text { M. } 1515\end{array}$ & $1518 ?-1530 ?$ & OTP & \begin{tabular}{|l} 
Councillor \\
$1530-1534^{31}$ \\
\end{tabular} \\
\hline 25. & \begin{tabular}{|l} 
Jan Kaňha \\
z Veleslavína
\end{tabular} & NTP - NTP 1599 & \begin{tabular}{|l|} 
Bc. 1570 \\
M. 1572 \\
\end{tabular} & $1577-1580$ & NTP & $\begin{array}{l}\text { Scribe in NTP, since } \\
1599 \text { councillor }^{32}\end{array}$ \\
\hline 26. & \begin{tabular}{|l|} 
Jan Karlík \\
Žlutický
\end{tabular} & $\begin{array}{l}\text { Lutitz (Žlutice) - } \\
\text { NTP } 1542\end{array}$ & \begin{tabular}{|l|} 
Bc. 1520 \\
M. 1522
\end{tabular} & $1524-1531 / 2$ & NTP & Scribe $^{33}$ \\
\hline 27. & Jan Kherner & $\begin{array}{l}\text { Pilsen - Prague } \\
1612\end{array}$ & \begin{tabular}{|l|} 
Bc. 1577 \\
M. 1584
\end{tabular} & $1585-1593$ & Prague & Lawyer \\
\hline 28. & $\begin{array}{l}\text { Valentin Kochan } \\
\text { z Prachové }\end{array}$ & $\begin{array}{l}\text { Strakonitz app. } \\
1565 \text { - OTP } 1621\end{array}$ & \begin{tabular}{|l|} 
Bc. 1586 \\
M. 1588 \\
\end{tabular} & $1594-1595 ?$ & NTP & Scribe $^{34}$ \\
\hline 29. & $\begin{array}{l}\text { Pavel Kristián } \\
\text { z Koldína }\end{array}$ & $\begin{array}{l}\text { Klattau } 1530 ?- \\
\text { Prague } 1589\end{array}$ & $\begin{array}{l}\text { Bc. } 1550 \\
\text { M. } 1552\end{array}$ & $1557-1562$ & OTP 1563 & $\begin{array}{l}\text { Scribe in NTP, } \\
\text { councillor in OTP } \\
1565-1567,{ }^{35} \text { after } \\
1568 \text { scribe in OTP, } \\
\text { later chancellor }\end{array}$ \\
\hline 30. & $\begin{array}{l}\text { Jan Kunštát } \\
\text { z Paumberka }\end{array}$ & $\begin{array}{l}\text { Prague } 1520- \\
\text { Prague } 1586\end{array}$ & $\begin{array}{l}\text { Bc. } 1539 \\
\text { M. } 1541 \\
\text { Dr. Med. } \\
\text { Bologna }\end{array}$ & $1543-1551$ & OTP & $\begin{array}{l}\text { Councillor 1556-1557, } \\
\text { 1565-1567,36 } \\
\text { physician }\end{array}$ \\
\hline
\end{tabular}

31 V. V. Tomeк, Dějepis města Prahy, IX, p. 415.

32 Jiří PEŠEK, Mistr Jan Kaňha z Veleslavína - obyčejný život pražského profesora a měštana doby rudolfinské [Master Jan Kaňha z Veleslavína: The Ordinary Life of Prague Professor and Burgher of the Rudolfinian Era], AUC-HUCP 47/1-2, 2007, p. 166f; J. MendelovÁ, Soupis písařů Nového Města pražského, p. 250.

33 J. Mendelové, Soupis písařo Nového Města pražského, p. 244.

34 J. Mendelová, Soupis písařu Nového Města pražského, p. $253 \mathrm{f}$.

35 J. Douša, Seznamy staroměstských konšelü, p. 81.

36 J. Douša, Seznamy staroměstských konšelü, p. 74, 81. 


\begin{tabular}{|c|c|c|c|c|c|c|}
\hline & Name & $\begin{array}{l}\text { Place and year of } \\
\text { birth and death }\end{array}$ & $\begin{array}{l}\text { Graduation at } \\
\text { the Utraquist or } \\
\text { other university }\end{array}$ & Professorship & Domicile & $\begin{array}{l}\text { Career in the urban } \\
\text { milieu } \\
\text { (office and/or trade) }\end{array}$ \\
\hline 31. & Ondřej Lucinius & $\begin{array}{l}\text { Leitmeritz - } \\
\text { Leitmeritz } 1591\end{array}$ & $\begin{array}{l}\text { Bc. } 1552 \\
\text { M. } 1556\end{array}$ & $1561-1564$ & Leitmeritz & $\begin{array}{l}\text { Councillor } 1568- \\
1570,1575-1578, \\
1580-1581,1582- \\
1583,1585-1586, \\
1587-1589, \text { mayor } \\
1584-1585^{37}\end{array}$ \\
\hline 32. & $\begin{array}{l}\text { Prokop Lupáč } \\
\text { z Hlavačova }\end{array}$ & $\begin{array}{l}\text { OTP - Taus } \\
\text { (Domažlice) } 1587\end{array}$ & $\begin{array}{l}\text { Bc. } 1558 \\
\text { M. } 1561\end{array}$ & $1564-1569$ & \begin{tabular}{|l|} 
Taus \\
(Domažlice)
\end{tabular} & $\begin{array}{l}\text { Scribe to } 1571 \text {, then } \\
\text { councillor to his death } \\
\dagger^{38}\end{array}$ \\
\hline 33. & $\begin{array}{l}\text { Kryštof } \\
\text { Mathaebaeus }\end{array}$ & $\begin{array}{l}\text { Bohdaneč - } \\
\text { Chrudim ca. } 1658\end{array}$ & $\begin{array}{l}\text { Bc. } 1597 \\
\text { M. } 1604\end{array}$ & 1606 & Chrudim & $\begin{array}{l}\text { City elder, school } \\
\text { inspector, member of } \\
\text { 'viri literati' }\end{array}$ \\
\hline 34. & $\begin{array}{l}\text { Matouš } \\
\text { Mendicellus }\end{array}$ & Saaz-OTP? & \begin{tabular}{|l|} 
Bc. 1583 \\
M. 1584
\end{tabular} & $1584-1592$ & OTP 1592 & Scribe \\
\hline 35. & $\begin{array}{l}\text { Matyáš Molesynus } \\
\text { z Dielenperka }\end{array}$ & $\begin{array}{l}\text { Hor. Slatina } \\
\text { u Trenčína - } \\
\text { Prague } 1597\end{array}$ & \begin{tabular}{|l} 
Bc. 1566 \\
M. 1569 \\
Basel JUDr. \\
1579
\end{tabular} & $1570-1581$ & NTP & Councillor \\
\hline 36. & Jan Nepressius & $\begin{array}{l}\text { Böhmisch Trübau } \\
1562 \text { - Saaz } 1612\end{array}$ & $\begin{array}{l}\text { Bc. } 1581 \\
\text { M. } 1582\end{array}$ & $1582-1584$ & Saaz & $\begin{array}{l}\text { Headmaster, city elder, } \\
\text { councillor } 1589-1605 \text {, } \\
1610-1612, \text { mayor } \\
1606-1609^{39}\end{array}$ \\
\hline 37. & $\begin{array}{l}\text { Řehoř Orinus } \\
\text { z Chocemic }\end{array}$ & $\begin{array}{l}\text { Kuttenberg-- } \\
\text { NTP? } 1563\end{array}$ & $\begin{array}{l}\text { Wittenberg, } \\
\text { Padua, Ferrara } \\
\text { Dr. }\end{array}$ & $1537-1549$ & NTP & Lawyer \\
\hline 38. & $\begin{array}{l}\text { Nikodém } \\
\text { Chotěbořský } \\
\text { z Paumberka Sr. }\end{array}$ & $\begin{array}{l}\text { Chotěboř } 1522 \text { - } \\
\text { Prague } 1574\end{array}$ & \begin{tabular}{|l} 
Bc. 1543 \\
M. 1545
\end{tabular} & 1546 & OTP & $\begin{array}{l}\text { Scribe, later } \\
\text { chancellor; councillor } \\
1567-1574^{40}\end{array}$ \\
\hline 39. & $\begin{array}{l}\text { Jan Pachaeus } \\
\text { z Rájova }\end{array}$ & $\begin{array}{l}\text { Budin an der } \\
\text { Eger }- \text { Kolin } \\
1622\end{array}$ & $\begin{array}{l}\text { Bc. } 1578 \\
\text { M. } 1579\end{array}$ & $1580-1583$ & Kolin & $\begin{array}{l}\text { Scribe } 1583-1584, \\
\text { mayor } 1585 \text {, royal } \\
\text { reeve } 1587-1621,41 \\
\text { school inspector, } \\
\text { member of 'viri } \\
\text { literati' }\end{array}$ \\
\hline
\end{tabular}

37 He probably remained member of the council also after 1589. Quido KASTNER, Obnovování městské rady $v$ Litoměricich ve 40. -80. letech 16. století. Soupis litoměrických purkmistrů [Renewing of the Town Council in Leitmeritz from 1540s until 1580s], Acta Litomericensia 1, 1981, p. 27-34, 47-48.

38 Biographic data included in the Handbook of Humanist Poetry were revised by Petr MužiK, Městská kancelár̆, správa a hospodárské poméry v Domažlicích v 16. a na počátku 17. století [Town Administration, Chancellery, and Economic Conditions in Domažlice in the 16th and Early 17th Century], Sborník archivních prací 27, 1977, p. 58-59.

39 Bohumír RoedL, Žatecká rodina Hoštálků z Javořice [Hošt’́lek z Javořice Family in Saaz], Žatec 1997, p. 24-250.

40 J. Douša, Seznamy staroměstských konšelů, p. 82-84.

41 F. RouBí, Královští rychtáři, p. 345. 


\begin{tabular}{|c|c|c|c|c|c|c|}
\hline & Name & $\begin{array}{c}\text { Place and year of } \\
\text { birth and death }\end{array}$ & $\begin{array}{l}\text { Graduation at } \\
\text { the Utraquist or } \\
\text { other university }\end{array}$ & Professorship & Domicile & $\begin{array}{l}\text { Career in the urban } \\
\text { milieu } \\
\text { (office and/or trade) }\end{array}$ \\
\hline 40. & $\begin{array}{l}\text { Jiří Polenta ze } \\
\text { Sudetu }\end{array}$ & $\begin{array}{l}\text { Kuttenberg } \\
1528 \text { - Prague } \\
1597\end{array}$ & $\begin{array}{l}\text { Bc. } 1548 \\
\text { M. } 1552\end{array}$ & $1553-1570$ & OTP & Physician \\
\hline 41. & $\begin{array}{l}\text { Václav } \\
\text { Posthumius } \\
\text { Bydžovský }\end{array}$ & $\begin{array}{l}\text { Sloupno near } \\
\text { Neu-Bidschow - } \\
\text { app. } 1616\end{array}$ & $\begin{array}{l}\text { Bc. } 1565 \\
\text { M. } 1576\end{array}$ & 1578 & OTP 1579 & \\
\hline 42. & $\begin{array}{l}\text { Simon Proxenus } \\
\text { ze Sudetu }\end{array}$ & $\begin{array}{l}\text { Budweis } 1532- \\
\text { Prague } 1575\end{array}$ & $\begin{array}{l}\text { Frankfurt/O. M. } \\
\text { Orléans Dr. jur. } \\
\text { utr. }\end{array}$ & $1556-1561 ?$ & OTP 1567 & $\begin{array}{l}\text { Councillor at the Court } \\
\text { of Appeals } 1567^{42}\end{array}$ \\
\hline 43. & Štěpán Prunerus & $\begin{array}{l}\text { Prague - Skalica } \\
\text { app. } 1631\end{array}$ & $\begin{array}{l}\text { Bc. } 1605 \\
\text { M. } 1606\end{array}$ & $1606-1609$ & Kolin 1613 & $\begin{array}{l}\text { Scribe in Kolin } 1609 \text {, } \\
\text { councillor } 1623 \text {, } \\
\text { school inspector, } \\
\text { financial clerk in } \\
\text { Kuttenberg } 1625 \text {, exile } \\
1626\end{array}$ \\
\hline 44. & $\begin{array}{l}\text { Bartoloměj Ropal } \\
\text { z Ryfmberka }\end{array}$ & Pacov- 1588 & \begin{tabular}{|l|} 
Bc. 1528 \\
M. 1534
\end{tabular} & $1534-1538 ?$ & $\begin{array}{l}\text { Chrudim, } \\
\text { NTP } 1548\end{array}$ & $\begin{array}{l}\text { Scribe in Chrudim } \\
1542-1548, \text { scribe in } \\
\text { NTP }^{43} 1548-1555\end{array}$ \\
\hline 45. & $\begin{array}{l}\text { Rosacius } \\
\text { z Karlšperka } \\
\text { Adam }\end{array}$ & $\begin{array}{l}\text { Schüttenhofen - } \\
\text { Schüttenhofen } \\
1624\end{array}$ & $\begin{array}{l}\text { Bc. } 1581 \\
\text { M. } 1584\end{array}$ & 1589-1594 & $\begin{array}{l}\text { Schütten- } \\
\text { hofen }\end{array}$ & $\begin{array}{l}\text { Repeatedly mayor } \\
1603-1605,1607- \\
1608,1615-1618, \\
\text { councillor } 1606, \\
1609-161444\end{array}$ \\
\hline 46. & Jan Rosacius & $\begin{array}{l}\text { Schüttenhofen - } \\
\text { Kolin } 1584\end{array}$ & $\begin{array}{l}\text { Bc. } 1573 \\
\text { M. } 1576\end{array}$ & $1580-1582$ & Kolin & Scribe $1583-1584$ \\
\hline 47. & $\begin{array}{l}\text { Jakub Srnovec } \\
\text { z Varvažova }\end{array}$ & $\begin{array}{l}\text { Rokitzan - OTP } \\
1586\end{array}$ & $\begin{array}{l}\text { Bc. } 1539 \\
\text { M. } 1541\end{array}$ & $\begin{array}{l}\text { Ca. } \\
1541-1548\end{array}$ & $\begin{array}{l}\text { OTP app. } \\
1548\end{array}$ & $\begin{array}{l}\text { Councillor 1554-1562; } \\
\text { councillor at the Court } \\
\text { of Appeals } 1562^{45}\end{array}$ \\
\hline 48. & $\begin{array}{l}\text { Jan Strial } \\
\text { z Pomnouše }\end{array}$ & $\begin{array}{l}\text { Saaz } 1535 \text { or } \\
1536 \text { - Saaz } 1582\end{array}$ & $\begin{array}{l}\text { Wittenberg M. } \\
1558\end{array}$ & $1563-1566$ & $\begin{array}{l}\text { Budweis } \\
1570, \text { Saaz } \\
1580 ?\end{array}$ & $\begin{array}{l}\text { Rector of the college } \\
\text { in Leitmeritz 1566; } \\
\text { scribe in Budweis } \\
1567 \text {, scribe in Saaz } \\
1580^{46}\end{array}$ \\
\hline
\end{tabular}

42 K. Wortschová, ,„...což slušného a spravedlivého jest fedrovati... “, p. 54.

43 J. Mendelová, Soupis písař̃ Nového Města pražského, p. $245 \mathrm{f}$.

44 Jan LнотÁк, K vývoji městské správy v Sušici od nejstaršich dob do roku 1850, III, Soupis zjištěných predstavitelů městské správy v Sušici [On the Evolution of Municipal Administration in Schüttenhofen Until 1850, III, List of Known Representatives of Municipal Administration in Schüttenhofen], Minulostí Západočeského kraje 45,2010 , p. 248-253. Personnel composition of the town council prior to 1603 has not been reconstructed due to absence of sources.

45 J. Douša, Seznamy staroměstských konšelů, p. 72-79; K. WortschovÁ, „,...což slušného a spravedlivého jest fedrovati...", p. 53.

46 Petra ŠŤovičKovÁ, Rekonstrukce osobni knihovny Jana a Bohuslava Strialia na základè souboru knih ze sbirek Severočeského muzea v Liberci [Reconstruction of Personal Library of Jan and Bohuslav Strial Based on Book Collection of the North Bohemian Museum in Liberec], Sborník Národního muzea v Praze, řada C, literární historie, 59/1-2, 2014, , p. 7-8. 


\begin{tabular}{|c|c|c|c|c|c|c|}
\hline & Name & $\begin{array}{c}\text { Place and year of } \\
\text { birth and death }\end{array}$ & $\begin{array}{l}\text { Graduation at } \\
\text { the Utraquist or } \\
\text { other university }\end{array}$ & Professorship & Domicile & $\begin{array}{l}\text { Career in the urban } \\
\text { milieu } \\
\text { (office and/or trade) }\end{array}$ \\
\hline 49. & $\begin{array}{l}\text { Gabriel Svěchinus } \\
\text { z Paumberka }\end{array}$ & $\begin{array}{l}\text { Chrudim } 1516- \\
\text { NTP } 1587\end{array}$ & $\begin{array}{l}\text { Bc. } 1544 \\
\text { M. } 1545 \\
\text { Bologna Dr. iur. }\end{array}$ & $1557-1558$ & NTP & $\begin{array}{l}\text { Councillor at the Court } \\
\text { of Appeals } 1557^{47}\end{array}$ \\
\hline 50. & Jan Šentygar & $\begin{array}{l}\text { Hvoždany } \\
1516 ?- \\
\text { Königgrätz } 1554\end{array}$ & $\begin{array}{l}\text { Bc. } 1536 \\
\text { M. } 1541\end{array}$ & $1541-1548$ & $\begin{array}{l}\text { Königgrätz } \\
1548\end{array}$ & $\begin{array}{l}\text { Physician / } \\
\text { apothecary } 48\end{array}$ \\
\hline 51. & Zachariáš Štyrský & $\begin{array}{l}\text { Prague } 1576- \\
\text { OTP } 1612\end{array}$ & $\begin{array}{l}\text { Bc. } 1595 \\
\text { M. } 1596\end{array}$ & $1600-1603$ & OTP 1608 & $\begin{array}{l}\text { Scribe in } \\
\text { Zehnter's office } 1605\end{array}$ \\
\hline 52. & $\begin{array}{l}\text { Jiří Šultys } \\
\text { z Felsdorfu }\end{array}$ & $\begin{array}{l}\text { Kuttenberg - } \\
\text { Verona }\end{array}$ & $\begin{array}{l}\text { Bc. } 1615 \\
\text { M. } 1615\end{array}$ & $1615-1622 ?$ & OTP 1618 & \\
\hline 53. & $\begin{array}{l}\text { Jan Tetaur ze } \\
\text { Svinčan }\end{array}$ & \begin{tabular}{|l|} 
Svinčany - \\
Leitmeritz 1617
\end{tabular} & \begin{tabular}{|l|} 
Bc. 1603 \\
M. 1604
\end{tabular} & $1605-1614$ & $\begin{array}{l}\text { Leitmeritz } \\
1616\end{array}$ & \\
\hline 54. & Mikuláš Troilus & $\begin{array}{l}\text { Svaté Pole } 1571 \text { - } \\
\text { Pirna } 1631\end{array}$ & \begin{tabular}{|l|} 
Bc. 1593 \\
M. 1600
\end{tabular} & $1603-1622$ & OTP & $\begin{array}{l}\text { Chancellor in OTP } \\
1619\end{array}$ \\
\hline 55. & Tomáš Vlašimský & & \begin{tabular}{|l|} 
Bc. 1508 \\
M. 1513
\end{tabular} & $\begin{array}{l}\text { Ca. } \\
1516-1529\end{array}$ & $\begin{array}{l}\text { Rakonitz } \\
1529\end{array}$ & Councillor 1534, 1543 \\
\hline 56. & Václav Vlaverin & $\begin{array}{l}\text { Nosislav - NTP } \\
1631 ?\end{array}$ & $\begin{array}{l}\text { Bc. } 1583 \\
\text { M. } 1588\end{array}$ & $1590-1604$ & NTP 1604 & $\begin{array}{l}\text { Councillor 1611- } \\
1617,1620-1622, \\
1628-1630^{49}\end{array}$ \\
\hline 57. & Jan Vocorineus & $\begin{array}{l}\text { Luditz (Žlutice) - } \\
\text { Prague } 1607\end{array}$ & $\begin{array}{l}\text { Bc. } 1583 \\
\text { M. } 1588\end{array}$ & $1593-1596$ & OTP 1596 & Scribe in OTP \\
\hline 58. & $\begin{array}{l}\text { Adam Vodička } \\
\text { z Radkova }\end{array}$ & Saaz-NTP 1560 & $\begin{array}{l}\text { Wittenberg M. } \\
1543\end{array}$ & $1546-1550 ?$ & NTP 1554 & $\begin{array}{l}\text { Rector of college } \\
\text { in Leitmeritz 1550, } \\
\text { chancellor in NTP }\end{array}$ \\
\hline 59. & $\begin{array}{l}\text { Daniel } \\
\text { Vratislavský }\end{array}$ & $\begin{array}{l}\text { Jungbuzlau - } \\
\text { Dresden after } \\
1636 ?\end{array}$ & $\begin{array}{l}\text { Bc. } 1605 \\
\text { M. } 1608\end{array}$ & $1610-1612$ & OTP 1612 & $\begin{array}{l}\text { Councillor } 1619-1620, \\
\text { school inspector, died } \\
\text { in exile } 5\end{array}$ \\
\hline 60. & $\begin{array}{l}\text { Jan Záhrobský } \\
\text { z Těšína }\end{array}$ & $\begin{array}{l}\text { Záhrobí by } \\
\text { Blatná - Klattau } \\
1590\end{array}$ & $\begin{array}{l}\text { Bc. } 1543 \\
\text { M. } 1545\end{array}$ & 1549 & Klattau & $\begin{array}{l}\text { Scribe in Böhmisch- } \\
\text { Brod and Klattau }\end{array}$ \\
\hline 61. & $\begin{array}{l}\text { Adam Zalužanský } \\
\text { ze Zalužan }\end{array}$ & $\begin{array}{l}\text { Münchengrätz } \\
1552 \text { - Prague } \\
1613\end{array}$ & $\begin{array}{l}\text { Bc. } 1581 \\
\text { M. } 1584 \\
\text { Dr. Med. } \\
\text { Helmstedt } \\
\end{array}$ & $1588-1594$ & OTP & Physician, apothecary \\
\hline 62. & $\begin{array}{l}\text { Jakub Žabonius } \\
\text { z Vyšetína }\end{array}$ & $\begin{array}{l}\text { Raudnitz a. L. } \\
1586 \text { - Prague }\end{array}$ & $\begin{array}{l}\text { Bc. } 1605 \\
\text { M. } 1610\end{array}$ & $1615-1621$ & ОТР 1618 & \\
\hline 63. & Jan Žabonius & Minice - ? & $\begin{array}{l}\text { Bc. } 1564 \\
\text { M. } 1569\end{array}$ & $1570-1571$ & NTP? & $\begin{array}{l}\text { Headmaster of the } \\
\text { School of St. Henry in } \\
\text { the NTP }\end{array}$ \\
\hline
\end{tabular}

47 K. WoItschová, ,, ...což slušného a spravedlivého jest fedrovati... “, p. 52.

48 Jaromír Miкulka, Dějiny Hradce Králové [History of Königgrätz], I/2, Hradec Králové 1997, p. 295.

49 J. Mendelová, Rada Nového Města pražského, p. 92-95.

50 J. Douša, Seznamy staroměstských konšelů, p. $103 \mathrm{f}$. 


\title{
Grant support:
}

This study was completed as part of research project of the Czech Science Foundation Universitas magistrorum. Professors of Prague Utraquist University (1458-1622) (reg. no. GACR 18-00408S).

\author{
MAREK ĎURČANSKÝ
}

\section{PROFESOŘI PRAŽSKÉ UTRAKVISTICKÉ UNIVERZITY A JEJICH KARIÉRY V MĚSTSKÉM PROSTŘEDÍ (1526-1622)}

\section{RESUMÉ}

Jádrem př́spěvku je prosopografie 93 osob, které vyučovaly na pražské univerzitě v letech 1526-1622, především pak těch, které se po jisté době usadily v městském prostředí ( 63 osob). Rozboru výsledků prosopografie předchází text sumarizující dosavadní literaturu zabývající se vztahem pražské univerzity a českých měst v prredbělohorské době. Tento vztah spočíval především na trojím základu: 1) na politické spolupráci městského stavu jako celku s univerzitou; 2) městském původu naprosté většiny studentů a profesorů; 2) síti městských škol spadajících pod odborný dohled rektora pražské univerzity dosazujícího na ně učitele.

Výsledky prosopografie se zaměřují na dvě hlavní otázky: místa původu a pozdějšího působení profesorů pražské univerzity a převažující modely jejich kariér v městském prostředí. Takřka dvě třetiny ze zkoumaných 63 osob pocházely z královských měst, zbytek připadá na poddanská města a vesnice. Všichni bez rozdílu se ale po odchodu z univerzity usadili ve větších královských městech, rozhodující měrou (41) v Praze. Takřka polovina $\mathrm{z}$ nich (27) během svého života po nějakou dobu působila na některém z písařských postů v městské kanceláři (zpravidla radní písař); zhruba stejný počet (26) také během své kariéry v městském prostředí zasedal v městské radě. I další posty v městské samosprávě a profese s ní spojené, kde bývalí profesoři působili, potvrzují významnou roli, kterou pražská univerzita hrála ve vývoji kultury a vzdělanosti českých měst v předbělohorském období.

PhDr. Marek Ďurčanský, Ph.D.

Ústav dějin a archiv Univerzity Karlovy

marek.durcansky@ruk.cuni.cz 